\title{
Sensitivitas Metode Pemeriksaan Mikroskopis Fluorokrom dan Ziehl-Neelsen untuk Deteksi Mycobacterium tuberculosis pada Sputum
}

\author{
Betty Suryawati ${ }^{1}$, Leli Saptawati ${ }^{1}$, Astari Febyane Putri ${ }^{2}$, Jatu Aphridasari ${ }^{3}$ \\ 1.Bagian Mikrobiologi Fakultas Kedokteran Universitas Sebelas maret \\ 2.Program Pendidikan Dokter Fakultas Kedokteran Universitas Sebelas Maret \\ 3.Bagian Ilmu Penyakit Paru, Fakultas Kedokteran Universitas Sebelas Maret \\ E-mail : betty.suryawati@staff.uns.ac.id
}

\begin{abstract}
ABSTRAK
Pendahuluan: Teknik pewarnaan fluorokrom (Auroamine-rhodamine) merupakan salah satu metode untuk deteksi Bakteri Tahan Asam (BTA) pada sampel sputum. Penelitian sebelumnya menunjukkan bahwa fluorokrom mempunyai sensitivitas yang lebih baik dari pada metode Ziehl-Neelsen (ZN). Walaupun demikian tetapi metode ini belum banyak digunakan secara rutin, termasuk di Indonesia. Penelitian ini bertujuan untuk untuk mengevaluasi sensitivitas, spesifisitas, dan biaya metode fluorokrom dan membandingkan dengan pewarnaan $\mathrm{ZN}$ untuk deteksi BTA pada sputum pasien dengan tuberculosis (TB) dan yang terduga TB.

Metode Penelitian: Subyek penelitian adalah 60 sampel sputum pasien TB dan tersangka TB yang dikirim ke Laboratorium Mikrobiologi Rumah Sakit Dr. Moewardi. Sampel diambil secara consecutive. Tiap sampel diperiksa dengan teknik pewarnaan $\mathrm{ZN}$ dan fluorokrom, dan ditanam pada media Lowenstein-Jensen (LJ) sebagai gold standar. Data dianalisis dengan uji sensitivitas dan spesifisitas.

Hasil Penelitian: Pemeriksaan ZN mendeteksi BTA pada 10 sampel sedangkan fluorokrom mendeteksi BTA pada 17 sampel. Sensitivitas dan spesifisitas metode ZN adalah $70 \%$ dan $90 \%$, sedangkan pada teknik flourokrom adalah $90 \%$ dan $84 \%$.

Simpulan: Teknik fluorokrom memiliki sensitivitas lebih tinggi dibanding ZN. Teknik ini dapat direkomendasikan untuk deteksi dini kasus tuberkulosis di Indonesia.
\end{abstract}

Kata Kunci: Tuberkulosis, Basil Tahan Asam, Fluorokrom, Ziehl-Neelsen

\begin{abstract}
Background: Detection of fast acid bacteria (FAB) using smear microscopy is used as a primary screening for tuberculosis diagnosis. Previous studies have shown that fluorochrome (Auroamine-rhodamine) staining showed better sensitivity compared to Ziehl-Neelsen (ZN) method in the detection of FAB in sputum. However this method has not been recommended for routine use including in Indonesia. This study aimed to evaluate the sensitivity and specificity of fluorochrome compared to $Z N$ to detect FAB in patient's sputum.

Methods: This study analyzed 60 sputum samples from patients with tuberculosis and suspected pulmonary tuberculosis. Samples were obtained consecutively from microbiology laboratory Moewardi Hospital, Indonesia. Each sample was examined using ZN and fluorochrome staining and cultured in Lowenstein-Jensen (LJ) medium. Data were analyzed using sensitivity and spesificity tests.

Results: ZN staining detected $F A B$ in 12 samples (10\%), while fluorochrome detected $F A B$ in 17 samples (28\%). The sensitivity and specificity of $Z N$ staining were $70 \%$ and $90 \%$ while these for fluorochrome were $90 \%$ and $84 \%$.
\end{abstract}


Conclusions: The sensitivity of fluorochrome staining is better compared to ZN staining.

This method can be recommended for early detection of tuberculosis.

Keywords: Tuberculosis, Acid Fast Bacilli; Fluorochrome; Ziehl-Neelsen staining

\section{PENDAHULUAN}

Tuberkulosis (TB) merupakan infeksi yang disebabkan oleh Mycobacterium tuberculosis ${ }^{1}$. Penyakit ini merupakan 10 besar penyakit terbanyak yang menyebabkan kematian diseluruh dunia ${ }^{2}$. Indonesia merupakan salah satu negara dengan prevalensi infeksi TB yang tinggi. Diperkirakan terdapat 1 juta kasus baru TB pada tahun $2015^{1}$. Kecepatan dan ketepatan diagnosis TB merupakan dasar keberhasilan pengobatan $\mathrm{TB}^{3}$.

Pemeriksaan mikroskopis dengan metode pewarnaan Ziehl-Neelsen (ZN) masih menjadi pilihan pertama untuk deteksi awal TB. Teknik ZN merupakan teknik yang mudah, murah, dan mempunyai spesifisitas yang tinggi untuk mendeteksi bakteri tahan asam (BTA) pada sputum. Akan tetapi penelitian melaporkan bahwa sensitivitasnya cukup rendah $(20-60 \%)^{4,5}$. Selain teknik ZN, pemeriksaan mikroskopis dengan mikroskop fluoresen dengan pawarnaan fluorokrom (Auroamine-rhodamine) sudah digunakan dibeberapa negara. Penelitian sebelumnya memperlihatkan bahwa pewarnaan fluorokrom mempunyai sensitivitas dan spesifisitas yang lebih baik dari pada $\mathrm{ZN}^{6}$. Akan tetapi di Indonesia, teknik ini belum direkomendasikan untuk digunakan secara rutin di laboratorium. Hal ini karena teknik ini memerlukan peralatan yang relatif mahal. Akan tetapi pada saat ini tersedia mikroskop fluoresen deangan harga yang relatif terjangkau misalnya dengan adanya teknologi LED microscopy ${ }^{7,8}$. Selain itu, adanya stigma bahwa pemeriksaan fluorokrom merupakan teknik yang sulit dikerjakan dan mahal membuat teknik ini belim direkomendasikan untuk pemeriksaan rutin diagnosis awal TB di Indonesia. Oleh karena itu diperlukan evaluasi penggunaan teknik ini di rumah sakit daerah untuk melihat efektivitasnya dibandingkan dengan teknik rutin pewarnaan $\mathrm{ZN}$.

Penelitian ini bertujuan untuk mengevaluasi sensitivitas dan spesifisitas teknik pewarnaan fluorokrom dibandingkan dengan pewarnaan $\mathrm{ZN}$ untuk deteksi BTA pasien TB dan pasien tersangka TB di rumah sakit pendidikan di Indonesia.

\section{METODE PENELITIAN}

Penelitian ini adalah penelitian eksperimental laboratorik dengan desain untuk uji diagnostik. Penelitian dilaksanakan di Laboratorium Mikrobiologi Universitas Sebelas Maret dan Laboratorium Mikrobiologi Klinik RSUD Dr. Moewardi. Sampel sputum diambil dari pasien dengan diagnosis TB atau pasien tersangka TB yang melakukan pemeriksaan di Balai Besar Kesehatan Para Masyarakat (BBKPM) Surakarta pada bulan Februari-Oktober 2017. Sampel sputum sebanyak 60 yang diambil secara consecutive sampling, pasien tersangka TB paru maupun yang telah terdiagnosis TB paru. Setiap sampel dilakukan pemeriksaan dengan teknik pewarnaan $\mathrm{ZN}$, fluorokrom dan ditanam pada media Lowenstein Jensen (LJ).

Teknik pewarnaan ZN dilakukan dengan membuat sediaan apusan sputum pada object glass. Kemudian dituangkan larutan carbol fuchsin $0,3 \%$ pada seluruh permukaan sediaan (apusan sputum). Setelah itu dipanaskan diatas nyala api sampai keluar asap (tetapi tidak sampai mendidih atau kering) selama 5 menit. Sediaan dibiarkan kering di udara selama 5-7 menit. Kelebihan cat dibuang dan dicuci dengan air yang mengalir. Setelah itu sediaan di beri larutan asam alkohol 3\% (hydrochloric acid-ethanol) dan dibiarkan 2-4 menit kemudian dicuci 
dengan air mengalir selama 1-3 menit. Setelah itu dituang larutan methylene blue 0,1\% sampai menutup seluruh permukaan dan ditunggu selama 1 menit kemudian larutan dibuang dan dicuci dengan air mengalir ${ }^{6}$.

Metode fluorokrom dilakukan dengan merendam sediaan (apusan sputum pada object glass) dalam larutan Auraminerhodamine) selama 15 menit. Sediaan dicuci dengan $\mathrm{H} 2 \mathrm{O}$ destilata dan dikeringkan, kemudian direndam dalam asam alkohol selama 2 menit. Setelah itu dicuci dengan $\mathrm{H} 2 \mathrm{O}$ destilata dan dikeringkan. Setelah itu sediaan direndam lagi dalam potasium permanganat $0,5 \%$ selama 2 menit. Yang terakhir, sediaan dicuci dengan $\mathrm{H} 2 \mathrm{O}$ destilata dan dikeringkan di udara ${ }^{6}$.

Pembacaan hasil teknik ZN dilakukan dengan mikroskop pembesaran 1000x dengan meneteskan minyak emersi pada sediaan. Pembacaan pada metode fluorokrom dengan mikroskop fluoresen pembesaran 400X. Pembacaan hasil jumlah BTA berdasarkan skala IUATLD (International Union Againts Tuberculosis and Lung Diseases, lihat Tabel 1).

Tabel 1. Skala IUATLD (International Union Againts Tuberculosis and Lung Diseases

\begin{tabular}{|l|c|}
\hline $\begin{array}{c}\text { Pembacaan dibawah } \\
\text { mikroskop }\end{array}$ & Pelaporan Hasil \\
\hline $\begin{array}{l}\text { Tidak ditemukan BTA } \\
\text { pada 100 lap pandang }\end{array}$ & Neg. \\
\hline $\begin{array}{l}\text { 1-9 BTA dalam 100 } \\
\text { lapangan pandang }\end{array}$ & $\begin{array}{c}\text { Tulis jumlah BTA } \\
\text { yang ditemukan }\end{array}$ \\
\hline $\begin{array}{l}\text { 10-99 BTA dalam 100 } \\
\text { lapangan pandang }\end{array}$ & +1 \\
\hline $\begin{array}{l}\text { 1-10 BTA dalam 1 } \\
\text { lapangan pandang }\end{array}$ & +2 \\
\hline $\begin{array}{l}>10 \text { BTA dalam 1 } \\
\text { lapangan pandang }\end{array}$ & +3 \\
\hline
\end{tabular}

Analisis statistik dilakukan dengan uji sensitivitas dan spesifisitas, nilai prediktif positif dan nilai prediktif negatif dari kedua teknik pemeriksaan dibandingkan dengan gold standar (baku-emas) yaitu pertumbuhan/ kultur pada medium LJ.

\section{HASIL PENELITIAN}

Visualisasi mikroskopis BTA dengan pewarnaan fluorochrome dan ZN

Pemeriksaan mikroskopis dengan fluorokrom memberikan gambaran kuman BTA seperti terlihat pada Gambar 1 (A) dan BTA pada pewarnaan ZN pada Gambar 1 (B).
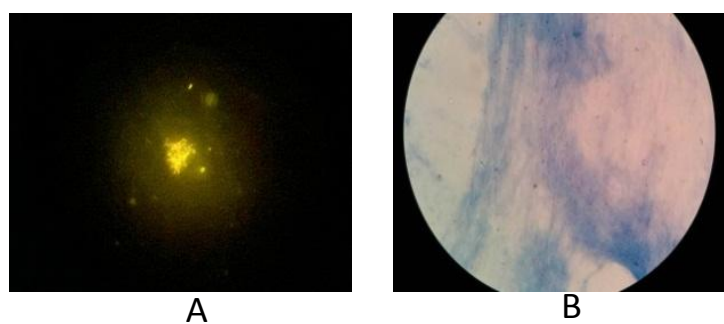

Gambar 1.

Hasil visualisasi mikroskopis pewarnaan BTA dengan metode pewarnaan fluorochrome (A) dan pewarnaan $\mathrm{ZN}$ (B)

\section{Perbandingan hasil deteksi BTA pada sputum dan hasil pertumbuhan pada medium Lowenstein Jensen}

Dari 60 sampel sputum yang diperiksa, $10(17 \%)$ sampel menunjukkan pertumbuhan pada medium LJ. Perbandingan hasil identifikasi BTA pada sampel sputum dengan metode fluorokrom dan hasil kultur ditunjukkan pada Tabel 2. Perbandingan hasil pewarnaan ZN terhadap kultur ditunjukkan pada Tabel 3. Hasil Pewarnaan fluorokrom dan $\mathrm{ZN}$, berturutturut menunjukkan hasil positif pada 10 sampel (28\%) dan 10 sampel (20\%) dari 60 sampel sputum yang diperiksa.

Nilai sensitivitas dan spesifisitas pewarnaan $\mathrm{ZN}$ adalah $70 \%$ dan $90 \%$. Nilai positive predictive value (PPV) dan nilai negative predictive value (NPV) pewarnaan ZN adalah 58\% dan 94\% (Lihat Tabel 4). Nilai sensitivitas dan spesifisitas teknik pewarnaan fluorokrom adalah $90 \%$ dan $84 \%$, 
PPV dan NPV untuk teknik fluorokrom adalah 53\% dan 98\% (lihat Tabel 5).

Tabel 2. Hasil pewarnaan fluorokrom terhadap kultur pada medium LJ.

\begin{tabular}{ccc}
\hline Interpretasi Hasil & \multicolumn{2}{c}{ Kultur pada medium LJ } \\
\cline { 2 - 3 } Pewarnaan & Kultur pos. & Kultur neg. \\
Fluorokrom & & 0 \\
\hline $3+$ & 3 & 3 \\
$2+$ & 3 & 1 \\
$1+$ & 1 & 4 \\
Scanty/rare & 2 & 42 \\
Neg. & 1 & 50 \\
\hline Total & 10 &
\end{tabular}

Ket: Pos=positif, Neg= Negatif

Tabel 3. Hasil pewarnaan ZN terhadap kultur pada medium LJ.

\begin{tabular}{ccc}
\hline $\begin{array}{c}\text { Interpretasi Hasil } \\
\text { Perwarnaan ZN }\end{array}$ & \multicolumn{2}{c}{ Kultur pada medium LJ } \\
\cline { 2 - 3 } & $\begin{array}{c}\text { Kultur } \\
\text { pos. }\end{array}$ & $\begin{array}{c}\text { Kultur } \\
\text { neg. }\end{array}$ \\
\hline $3+$ & 3 & 0 \\
$2+$ & 0 & 2 \\
$1+$ & 4 & 3 \\
1-9 BTA/100LP & 0 & 0 \\
Neg. & 3 & 45 \\
\hline Total & 10 & 50 \\
\hline Tet: Pol
\end{tabular}

Ket: Pos=positif, Neg= Negatif

Sebanyak 14 sampel pada masingmasing pewarnaan memberikan hasil yang berbeda dengan hasil pertumbuhan pada medium LJ. Sepuluh sampel memberikan hasil BTA positif pada salah satu atau kedua macam pewarnaan tetapi tidak menunjukkan adanya pertumbuhan Mycobacterium sp. pada medium LJ, meskipun masa inkubasi telah dilakukan hingga 8 minggu.

Tabel 4. Pemeriksaan mikroskopis sputum dengan metode $\mathrm{ZN}$ dibandingkan dengan kultur pada medium LJ.

\begin{tabular}{l|l|ccc}
\hline \multicolumn{2}{c}{} & \multicolumn{3}{c}{ Kultur LJ } \\
\hline \multicolumn{2}{c}{} & Pos. & Neg. & Jumlah \\
\hline ZN & Pos. & 7 & 5 & 12 \\
& Neg. & 3 & 45 & 48 \\
\hline & Jumlah & 10 & 50 & 60 \\
\hline
\end{tabular}

Ket: Pos=positif, Neg= Negatif
Tabel 5. Pemeriksaan mikroskopis sputum dengan metode fluorokrom dibandingkan dengan kultur pada medium LJ.

\begin{tabular}{l|l|ccc}
\hline \multicolumn{2}{l}{} & \multicolumn{3}{c}{ Kultur LJ } \\
\hline \multicolumn{2}{l}{} & Pos. & Neg. & Jumlah \\
\hline Fluoro- & Pos. & 9 & 8 & 17 \\
krom & Neg. & 1 & 42 & 43 \\
\hline & Jumlah & 10 & 50 & 60 \\
\hline
\end{tabular}

Ket: Pos=positif, Neg= Negatif

\section{PEMBAHASAN}

Pemeriksaan mikroskopis sputum merupakan pemeriksaan awal yang sederhana, cepat, murah, dan cukup sensitif untuk menegakkan diagnosis TB paru. Sensitivitas pemeriksaan mikroskopis sputum dipengaruhi oleh beberapa faktor seperti prevalensi tuberkulosis, kualitas dan jumlah spesimen, metode pewarnaan, dan skill dari analisis ${ }^{9}$. Penelitian ini membandingkan metode pewarnaan $\mathrm{ZN}$ yang dibaca menggunakan mikroskop cahaya biasa dengan emersi pembesaran 100X dan teknik fluorokrom yang dibaca menggunakan mikroskop fluorosens dengan pembesaran 400X.

Hasil penelitian didapatkan bahwa sensitivitas metode pewarnaan $\mathrm{ZN}$ dan fluorokrom masing-masing sebesar $70 \%$ dan 90\%. Sesuai dengan penelitian-penelitian sebelumnya, BTA pada sputum dengan pewarnaan ZN akan menunjukkan hasil positif bila sputum mengandung paling sedikit $10^{5}$ $\mathrm{BTA} / \mathrm{ml}$, sedangkan metode pewarnaan yang lebih sensitif seperti fluorokrom dapat mendeteksi BTA dengan jumlah minimal $10^{4}$ $\mathrm{BTA} / \mathrm{ml}{ }^{10}$. Metode pewarnaan fluorokrom juga memiliki keuntungan berupa pembacaan hasil yang lebih mudah dan cepat, karena pembesaran yang lebih kecil sehingga lapang pandang per unit lebih besar. Pembacaan hasil metode pewarnaan $\mathrm{ZN}$ diperlukan pembesaran 100x lensa objektif dan 10x lensa okuler, sedangkan pada metode pewarnaan fluorokrom hanya diperlukan pembesaran 40x lensa objektif dan 10x lensa okuler. Metode 
pewarnaan fluorokrom menggunakan zat warna auramine-rhodamine/KMnO4, BTA akan tampak berwarna kuning oranye dengan latar bewarna gelap seperti pada Gambar 19 . Diperlukan waktu sekitar 2 menit dengan mikroskop fluorosens untuk pembacaan hasil per area sementara dengan mikroskop cahaya biasa dibutuhkan waktu 10 menit ${ }^{11}$.

Spesifisitas dan nilai NPP pewarnaan fluorokrom pada penelitian ini sedikit lebih rendah dibandingkan dengan pewarnaan $\mathrm{ZN}$, yaitu $84 \%$ dibanding $90 \%$. Beberapa penelitian sebelumnya menunjukkan bahwa spesivitas dan sensitivitas metode fluorokrom cukup tinggi bahkan mencapai $100 \%{ }^{12}$. Angka spesifisitas yang lebih rendah dapat terjadi karena pemeriksaan dengan teknik fluorokrom juga dapat mendeteksi jaringan non spesifik, debris sel, atau bakteri lain yang sudah mati ${ }^{13}$. Hal ini dapat diatasi dengan membuat kualitas sediaan sputum yang baik pada proses pewarnaan.

Dari segi biaya pemeriksaan mikroskopis, metode pewarnaan fluorokrom lebih murah dibandingkan dengan metode $\mathrm{ZN}$, biaya masing-masing adalah Rp. 4000 per sampel untuk Fluorokrom dan Rp. 15.000 per sampel untuk ZN. Masih jarangnya penggunaan metode pewarnaan fluorokrom di Indonesia kemungkinan disebabkan oleh harga mikroskop fluorosens yang lebih mahal dibandingkan dengan mikroskop cahaya biasa, tetapi mikroskop fluorosens hemat daya seperti mikroskop fluorosens Light-Emitting Diode (LED) dapat dijadikan alternatif supaya biaya menjadi lebih efektif. Penelitian di Negara dengan kondisi ekonomi yang terbatas menunjukkan bahwa metode pemeriksaan fluorokrom sangat ideal untuk diterapkan sebagai pemeriksaan rutin untuk deteksi dini TB ${ }^{14}$.

Mikroskop fluorosens biasa yang menggunakan sumber cahaya dari merkuri atau halogen, hanya dapat digunakan selama 150 jam. Sedangkan mikroskop fluorosens LED dapat digunakan selama 15.000 jam
(CLSI, 2008). Hal ini tentunya dapat mengurangi biaya secara signifikan sehingga metode pewarnaan BTA fluorokrom dapat mulai dikembangkan di negara-negara berkembang termasuk Indonesia dengan angka kejadian TB yang tinggi.

\section{SIMPULAN}

Pemeriksaan mikroskopis BTA dengan metode pewarnaan fluorokrom memiliki sensitivitas dan NPP yang lebih tinggi dibandingkan dengan metode pewarnaan $\mathrm{ZN}$. Metode ini dapat direkomendasikan sebagai pengganti metode $\mathrm{ZN}$, apalagi didukung biaya yang lebih murah.

\section{DAFTAR PUSTAKA}

1. Collins D, Hafidz F, Mustikawati D 2017 Int J Tuberc Lung Dis 21 1041-8

2. Dodd P J, Yuen C M, Sismanidis C, Seddon J A, Jenkins H E 2017 Lancet Glob Health 5 e898-e906

3. Lawn S D, Mwaba P, Bates M, Piatek A, Alexander H, Marais B J, et al. 2013 Lancet Infect Dis 13 349-61

4. Agrawal M, Bajaj A, Bhatia V, Dutt S 2016 J Clin Diagn Res 10 DC09-12

5. Shakeel K, Iram S, Akhtar M, Hussain S, Maryam H, Anwar A 2018 J Pak Med Assoc 68 33-7

6. Karuniawati A, Risdiyani E, Nilawati S, Prawoto, Rosana Y, Alisyahbana B, et al. 2005 MAKARA 9 29-33

7. Whitelaw A, Peter J, Sohn H, Viljoen D, Theron G, Badri M, et al. 2011 Eur Respir J 38 1393-7

8. Khatun Z, Kamal M, Roy C K, Sultana T, Rahman M Q, Azad M, et al. 2011 Bangladesh Med Res Counc Bull 37 7-10

9. O A, Nurbanu S, Aygün Ö, Nur Y, Sürücüoğlu S, Yüce A 2011 Turk J Med Sci 41 411-7

10. NS M, G A 2016 International Journal of Contemporary Medical Research 3 968-71

11. J B, Shahapur P, P C, SS H 2013 J. Pharm. Sci. \& Res 5 89-92

12. Shea Y R, Davis J L, Huang L, Kovacs J A, Masur H, Mulindwa F, et al. 2009 J Clin Microbiol 47 1553-5

13. J A, Caulfield, Nancy L, Wengenack 2016 Journal of Clinical Tuberculosis and Other Mycobacterial Diseases 4 33-43 
14. Alfred N, Lovette L, Aliyu G, Olusegun O, Meshak P, Jilang T, et al. 2014 BMJ Open 4 e004093 